\title{
Tingkat Kesehatan Bank dan Laba pada Bank Umum Syariah
}

\author{
Muhammad Hasbi Al Baihaqy \\ Universitas Muhammadiyah Prof. DR. HAMKA \\ albaihaqy12@gmail.com
}

\begin{abstract}
This study aims to test how the influence of bank soundness based on Risk Based Bank Rating method of Net Profit at Islamic Bank. Factors or ratios used in the Risk Based Bank Rating assessment include Non Performing Financing (NPF) Risk, Investment Risk (Composition and Level of Profit Sharing on Profit Sharing), Profitability (Operating Cost to Operating Income I BOPO) and Capital (Capital Adequacy Ratio / CAR). This study uses secondary data derived from the quarterly financial statements of Islamic banks in Indonesia period 20I2-2016 with a sample of 5 banks. This research uses panel data analysis method. The results of this study indicate that through the f-test shows that all variables affect the Profit of Islamic Bank. While through t-test variable NPF and BOPO have a significant and negative effect to Profit Islamic Bank. Variables of Composition and Level of Profit Sharing on Revenue Sharing have a significant and positive impact on Islamic Bank Profit. While the CAR variable has no effect on the profit of Islamic Bank.
\end{abstract}

Key Words: soundness, profit, Islamic banks

\begin{abstract}
Abstrak
Penelitian ini bertujuan untuk menguji bagaimana pengaruh tingkat kesehatan bank berdasarkan metode Risk Based Bank Rating terhadap Laba bersih pada Bank Umum Syariah. Faktor atau rasio yang digunakan dalam penilaian Risk Based Bank Rating mencakup Risiko Imbal Hasil (Non Performing Financing/NPF), Risiko Investasi (Komposisi dan Tingkat Konsentrasi Pembiayaan Berbasis Bagi Hasil), rentabilitas (Biaya Operasional terhadap Pendapatan Operasional/BOPO) dan permodalan (Capital Adequacy Ratio/CAR). Penelitian ini menggunakan data sekunder yang berasal dari laporan keuangan triwulan bank umum syariah di Indonesia periode 2012-2016 dengan sampel sebanyak 5 bank. Penelitian ini menggunakan metode analisis data panel. Hasil dari penelitian ini menunjukkan bahwa melalui uji-f menunjukkan bahwa seluruh variabel berpengaruh terhadap Laba Bank Umum Syariah. Sedangkan melalui uji-t variabel NPF dan BOPO berpengaruh signifikan dan negatif terhadap Laba Bank Umum Syariah. Variabel Komposisi dan Tingkat Konsentrasi Pembiayaan Berbasis Bagi Hasil berpengaruh signifikan dan positif terhadap Laba Bank Umum Syariah. Sedangkan variabel CAR tidak berpengaruh terhadap Laba Bank Umum Syariah.
\end{abstract}

Kata Kunci: tingkat kesehatan, laba, bank umum syariah

Diterima: 20 Januari 2017; Revisi: 3 Maret 2017; Disetujui: 30 Maret 2017 


\section{PENDAHULUAN}

Salah satu sarana yang mempunyai peranan strategis dalam kegiatan perekonomian adalah perbankan. Peran strategis tersebut disebabkan oleh fungsi utama perbankan sebagai lembaga intermediasi keuangan (Financial Intermediary), yaitu sebagai institusi yang dapat menghimpun dana dan menyalurkan dana masyarakat secara efektif dan efisien. Perbankan nasional memegang peranan dan strategis dalam kaitannya dengan penyediaan permodalan pengembangan sektor-sektor produktif, lembaga perbankan hampir ada pada setiap negara karena keberadaannya sangat penting, yaitu untuk meningkatkan kesejahteraan masyarakat dan perekonomian negara (Usanti dan Shomad, 2013). Perkembangan industri perbankan syariah nasional diawali oleh penyempurnaan UU No. 7/1992 menjadi UU No. 10 Tahun 1998, yang secara tegas menyatakan bahwa terdapat dua sistem dalam perbankan di tanah air (dual banking system), yaitu sistem perbankan konvensional dan sistem perbankan syariah. Pada umumnya suatu bank didirikan dengan tujuan untuk memperoleh laba yang optimal. Laba merupakan faktor penunjang kelangsungan hidup bank, dimana setiap aktivitas bank yang berupa transaksi dalam rangka menghasilkan laba dicatat, diklasifikasikan, dan disajikan dalam laporan keuangan, yang digunakan untuk mengukur hasil operasi bank pada suatu periode tertentu. Ukuran keberhasilan suatu bank dapat dilihat dari besar kecilnya laba. Sebab dengan laba yang diperoleh bank, merupakan ukuran keberhasilan bahwa bank telah bekerja secara efisien.

\section{Tabel I}

\section{Perkembangan Laba Bank Umum Syariah dan Unit Usaha Syariah}

(dalam miliar rupiah)

\begin{tabular}{cc}
\hline Tahun & Laba \\
\hline 2011 & 1.422 \\
2012 & 2.466 \\
2013 & 3.230 \\
2014 & 1.733 \\
2015 & 1.786 \\
2016 & 2.096
\end{tabular}

Sumber: Statistik Perbankan Syariah

Kemampuan bank dalam meningkatkan laba merupakan salah satu indikator bahwa bank tersebut memiliki kinerja yang baik dan memiliki prospek yang baik pula. Posisi laba yang dihasilkan oleh bank dapat dilihat di dalam laporan laba rugi yang 
terdapat dalam laporan keuangan. Pengguna laporan keuangan dapat melihat informasi laba dari tahun ke tahun. Dengan melihat pertumbuhan laba, investor dapat memberikan keputusan mengenai investasi mereka, apakah akan tetap melanjutkan investasi atau tidak (Novitasari, 2015). Informasi kinerja perbankan syariah, terutama profitabilitas, diperlukan untuk menilai perubahan potensial sumber daya ekonomi yang mungkin dikendalikan di masa depan. Informasi fluktuasi kinerja adalah penting dalam hubungan ini. Informasi kinerja bermanfaat untuk memprediksi kapasitas perbankan syariah dalam menghasilkan arus kas dari sumber daya yang ada.

Pada Tabel I data Otoritas Jasa Keuangan menunjukkan bahwa laba pada Bank Umum Syariah mengalami fluktuasi. Laba pada tahun 2012-2013 mengalami kenaikan dari 2.466 miliar menjadi 3.230 miliar. Pada tahun 2013-2014 laba mengalami penurunan yang signifikan dari 3.230 miliar menjadi 1.733 miliar. Kemudian mengalami sedikit peningkatan pada tahun 2015-2016. Kegiatan perbankan selalu berhubungan dengan resiko usaha, khususnya bank syariah yang memiliki lebih banyak resiko dibandingkan bank konvensional. maka Otoritas Jasa Keuangan berharap dengan dikeluarkannya kebijakan penilaian tingkat kesehatan bank syariah dan unit usaha syariah dengan metode Risk Based Bank Rating, manajemen resiko dan permodalan bank syariah meningkat sehingga kinerja bank syariah selalu dalam keadaan stabil dan meningkat. Harapan lainnya yaitu, dengan adanya metode penilaian Risk Based Bank Rating perbankan syariah terjaga kualitas pembiayaannya sehingga dapat mendorong pertumbuhan laba perbankan syariah (Nurdin dkk, 2016). Setelah ditetapkannya peraturan penilaian tingkat kesehatan Risk Based Bank Rating pertumbuhan kinerja bank syariah yang dilihat berdasarkan jumlah laba mengalami fluktuasi cenderung menurun pada tahun 2014 dan 20I5. Bisa dilihat pada Tabel I tahun 2014 rata-rata Return on Asset Bank Umum Syariah dan Unit Usaha Syariah mengalami penurunan yang sangat signifikan dari 2,00\% di tahun 2013 menjadi 0,80\% pada tahun 2014 yang menggambarkan bahwa kinerja bank sedang dalam keadaan buruk diperkuat dengan menurunnya laba dari tahun 2013 sebesar 3.230 menjadi I.733 pada tahun 2014 .

Beberapa Penelitian yang berkaitan dengan pengaruh tingkat kesehatan terhadap laba diantaranya, Teddy Rahman (2009) menyatakan bahwa variabel Capital Adequacy Ratio (CAR), Net Interest Margin (NIM), Loan Deposit Ratio (LDR), BOPO, Non 
Performing Loan (NPL) secara bersama-sama berpengaruh signifikan terhadap variabel perubahan laba. Sedangkan secara parsial dengan uji t, menunjukkan bahwa variabel Capital Adequacy Ratio (CAR), dan Loan Deposit Ratio (LDR) berpengaruh positif signifikan dan variabel BOPO, Non Performing Loan (NPL) berpengaruh negatif dan signifikan sedangkan variabel NIM berpengaruh positif tidak signifikan terhadap perubahan laba pada bank Non Devisa.

Tabel 2 Perbandingan Rasio Keuangan Terhadap Laba Bank Umum Syariah dan Unit Usaha Syariah

\begin{tabular}{ccccccc}
\hline Rasio & 20I I & 20I2 & 20I3 & 20I4 & 20I5” & 20I6” \\
\hline CAR (\%)” & 16,63 & 14,13 & 14,42 & 16,10 & 15,02 & 15,95 \\
ROA(\%) & 1,79 & 2,14 & 2,00 & 0,80 & 0,49 & 0,63 \\
NPF(\%) & 2,52 & 2,22 & 2,62 & 4,33 & 4,84 & 4,42 \\
FDR(\%) & 89,94 & 100,00 & 100,32 & 91,50 & 88,03 & 85,99 \\
BOPO(\%) & $78,4 I$ & 74,97 & 78,21 & 79,27 & 97,01 & 96,23 \\
Laba (miliar) & I.422 & 2.466 & 3.230 & 1.733 & 1.786 & 2.096 \\
\hline Ket: “) Hanya data Bank Umum Syariah & & & &
\end{tabular}

Ket: ") Hanya data Bank Umum Syariah

Sumber: Statistik Perbankan Syariah data diolah

Anisah Lubis (20I3), menyatakan bahwa variabel yang berpengaruh terhadap pertumbuhan laba yaitu variabel NPL sedangkan, variabel BOPO LDR dan CAR tidak berpengaruh terhadap pertumbuhan laba. Ahmad Buyung Nusantara (2009) menunjukkan bahwa NPL, CAR, LDR, dan BOPO secara parsial signifikan terhadap ROA bank go publik. Sedangkan pada bank non go public, hanya LDR yang berpengaruh signifikan.

Terdapat perbedaan hasil dari penelitian mengenai pengaruh CAR, LDR, NPL dan BOPO terhadap pertumbuhan laba. Hasil penelitian Teddy Rahman (2009) menunjukkan bahwa CAR dan LDR secara parsial berpengaruh positif signifikan, NPL dan BOPO secara parsial berpengaruh negatif signifikan. Sedangkan berbeda dengan hasil penelitian Anisah Lubis (2015) yang menunjukkan bahwa CAR dan LDR tidak berpengaruh terhadap pertumbuhan laba, dan NPL berpengaruh terhadap pertumbuhan laba.

Berdasarkan latar belakang yang telah diuraikan sebelumnya, maka penulis merumuskan masalah dalam penelitian ini adalah :Bagaimana pengaruh Risk Profile, 
Earning dan Capital dalam metode penilaian tingkat kesehatan bank Risk Based Bank Rating terhadap laba Bank Umum Syariah periode 2012-2016? Oleh karenanya penelitian ini berttujuan untuk menganalisis pengaruh Risk Profile, Earning dan Capital terhadap laba Bank Umum Syariah periode 2012-20I6.

\section{KAJIAN PUSTAKA}

Laba merupakan hasil operasi suatu perusahaan dalam satu periode akuntansi. Informasi laba ini sangat berguna bagi pemilik dan investor. Laba yang mengalami peningkatan merupakan kabar baik (good news) bagi investor, sedangkan laba yang mengalami penurunan merupakan kabar buruk (bad news) bagi investor (Hapsari, 2007).

Kesehatan bank dapat diartikan sebagai kemampuan suatu bank untuk melakukan kegiatan opersional perbankan secara normal dan mampu memenuhi semua kewajibannya dengan baik dengan cara-cara yang sesuai dengan peraturan perbankan yang berlaku. Pengertian tentang kesehatan bank diatas merupakan suatu batasan yang sangat luas, karena kesehatan bank mencakup kesehatan bank untuk melaksanakan seluruh kegiatan usaha perbankannya (Susilo dkk, 2000). Bank Umum Syariah wajib melakukan penilaian Tingkat Kesehatan Bank baik secara individual maupun secara konsolidasi. Unit Usaha Syariah wajib melakukan penilaian Tingkat Kesehatan Bank secara individual. Mekanisme penilaian tingkat kesehatan bank secara individual disebutkan dalam Peraturan otoritas jasa keuangan Nomor 8/pojk.03/20I4 pasal 6 ayat I bahwa Bank Umum Syariah wajib melakukan penilaian Tingkat Kesehatan Bank secara individual dengan cakupan penilaian terhadap faktor-faktor sebagai berikut: Profil Risiko (risk profil)

Penilaian terhadap faktor profil risiko merupakan penilaian terhadap resiko inheren dan kualitas penerapan manajemen risiko dalam operasional bank yang dilakukan terhadap 10 (sepuluh) risiko yaitu risiko kredit, risiko pasar, risiko likuiditas, risiko operasional, risiko hukum, risiko stratejik, risiko kepatuhan, risiko reputasi, risiko imbal hasil dan risiko investasi (Ikatan Bankir Indonesia dan Bankir Association for Risk Management, 2016). Dalam penelitian ini, profil risiko yang peneliti gunakan adalah risiko imbal hasil dan risiko investasi. Terdapat beberapa faktor dalam menilai profil risiko imbal hasil, antara lain dapat menggunakan Komposisi Dana Pihak 
Ketiga, strategi dan kinerja bank dalam menghasilkan laba/pendapatan dan perilaku nasabah dana pihak ketiga. Sedangkan dalam menilai profil risiko investasi faktor yang digunakan adalah, Komposisi dan Tingkat Konsentrasi Pembiayaan Berbasis Bagi Hasil, Kualitas Pembiayaan Berbasis Bagi Hasil dan Faktor Eksternal (Ikatan Bankir Indonesia dan Bankir Association for Risk Management, 2016). Dalam penelitian ini faktor yang digunakan untuk menilai Profil Risiko Imbal Hasil adalah strategi dan kinerja bank dalam menghasilkan laba/pendapatan yang diproksikan dengan rasio Non Performing Financing (NPF). Untuk menilai Profil Risiko Investasi faktor yang digunakan adalah Komposisi dan Tingkat Konsentrasi Pembiayaan Berbasis Bagi Hasil yang dihitung berdasarkan total pembiayaan berbasis bagi hasil dibagi dengan total pembiayaan.

\section{Good Corporate Governance}

Penilaian terhadap faktor Good Corporate Governance merupakan penelitian terhadap manajemen Bank Umum Syariah atas pelaksanaan prinsip-prinsip Good Corporate Governance.

Rentabilitas (earning)

Penilaian terhadap faktor rentabilitas meliputi penilaian terhadap kinerja renabilitas, sumber-sumber rentabilitas, dan stabilitas rentabilitas (sustainability earning) Bank Umum Syariah. Penelitian dilakukan dengan mempertimbangkan aspek tingkat, tren, struktur, dan stabilitas, dengan memperhatikan kinerja peer grup serta manajemen rentabilitas bank, baik melalui analisis aspek kuantitatif maupun kualitatif (Ikatan Bankir Indonesia dan Bankir Association for Risk Management, 2016).

Penilaian pendekatan kuantitatif dan kualitatif faktor rentabilitas antara lain dilakukan melalui penilaian terhadap komponen-komponen sebagai berikut: (I) Return on Assets; (2) Return on equity; (3) Net interest margin; (4) Biaya operasional dibandingkan dengan pendapatan operasional (BOPO); (5) Perkembangan laba operasional; (6) Komposisi portofolio aktiva produktif dan diversifikasi pendapatan; (7) Penerapan prinsip akuntansi dalam pengakuan pendapatan dan biaya; (8) Prospek laba operasional Permodalan (capital)

Penilaian terhadap faktor permodalan meliputi penilaian terhadap tingkat kecukupan permodalan dan pengelolaan permodalan Bank Umum Syariah. Penelitian terhadap tingkat kecukupan permodalan dan pengelolaan permodalan dilakukan bank 
dengan mempertimbangkan tingkat, tren, struktur, dan stabilitas, dengan memperhatikan kinerja peer grup serta manajemen permodalan bank, baik melalui analisis aspek kuantitatif maupun kualitatif (Ikatan Bankir Indonesia dan Bankir Association for Risk Management, 2016).

\section{METODE}

Penelitian ini menganalisis pengaruh tingkat kesehatan bank metode Risk Based Bank Rating dengan faktor penilaian berupa faktor profil risiko imbal hasil menggunakan rasio non performing financing (NPF), faktor profil resiko Investasi menggunakan nilai komposisi dan tingkat konsentrasi pembiayaan berbasis bagi hasil, faktor rentabilitas menggunakan rasio Beban Operasional Terhadap Pendapatan Operasional (BOPO) dan faktor permodalan menggunakan rasio Capital Adequacy Ratio (CAR) terhadap laba di Bank Umum Syariah. Penelitian ini bersifat kuantitatif atas data sekunder menggunakan data panel yaitu gabungan antara data time series dan cross section dalam kurun waktu 20I2-2016.

Kriteria yang ditentukan oleh penulis dalam pemilihan sampel bank syariah yaitu (I) Bank Umum Syariah Devisa. (2) Bank tersebut telah mengeluarkan laporan keuangan triwulan periode 2012-2016. Berdasarkan kriteria diatas, ada 5 BUS yang sesuai untuk dijadikan objek penelitian ini, yaitu Bank Mandiri Syariah, BRI Syariah, BNI Syariah, Bank Panin Dubai Syariah dan Bank Muamalat.

Teknik analisis data dalam penelitian ini adalah menggunakan analisis regresi data panel. Data panel adalah gabungan antara data runtut waktu (time series) dan data silang (cross section) (Basuki dan Prawoto, 2016). Model regresi panel, sebagai berikut:

Ln_Laba ${ }_{i t}=\alpha+\beta_{1}$ NPF $_{i t}+\beta_{2} C_{\text {it }}+\beta_{3}$ BOPO $_{i t}+\beta_{4}$ Ln_Komposisi dan Tingkat Konsentrasi Pembiayaan Bagi Hasil ${ }_{\mathrm{it}}+\varepsilon_{\mathrm{it}}$

\section{HASIL DAN PEMBAHASAN}

Untuk mengetahui model panel yang akan digunakan, maka digunakan uji FRestricted dengan cara melihat nilai (P-Value) F- Statistik lebih kecil dari tingkat signifikan $\alpha=5 \%$, terlebih dahulu dibuat hipotesisnya. Hasil Uji Chow diperoleh FStatistik sebesar 17.5005 dan nilai probabilitas F-Statistik sebesar 0.0000 yang berarti bahwa nilai probabilitas F-Statistik lebih kecil dari tingkat signifikansi a 5\% $(0.0000<$ 
0.05). maka HO ditolak, sehingga model panel yang digunakan adalah Fixed Effect Model (FEM).

Untuk mengetahui model panel yang digunakan, maka digunakan uji hausman. Pengujian ini untuk menentukan model paling tepat digunakan antara Fixed Effet Model (FEM) dengan Random Effect Model (REM). Uji hausman memberikan penilaian dengan menggunakan Chi-Square Statistic dan nilai a 5\% sehingga keputusan pemilihan model dapat ditentukan dengan tepat. Hasil Uji Hausman diperoleh nilai probabilitas sebesar 0.0000 yang berarti bahwa tingkat signifikansi a $5 \%(0.0000<0.05)$. Maka HO ditolak, sehingga model panel yang digunakan adalah Fixed Effect Model (FEM).

Model data panel yang digunakan dalam penelitian ini adalah dengan menggunakan Fixed Effect Model (FEM) dapat dijelaskan melalui persamaan sebagai berikut:

Ln_Laba $=14.87547-0.270372$ NPF -0.026179 CAR -0.045325 BOPO + 3.754416 Ln_PBGH

Dimana :

NPF : Non Performing Financing

CAR : Capital Adequacy Ratio

BOPO : Biaya operasional terhadap pendapatan operasional

PBGH : Komposisi dan tingkat konsentrasi pembiayaan berbasis bagi hasil

Tabel 3 merupakan hasil dari penelitian variabel independen NPF, CAR, BOPO dan Komposisi dan Tingkat Konsentrasi Pembiayaan Bagi Hasil terhadap Laba Bank Umum Syariah secara parsial. Tabel 4.4 menunjukkan bahwa koefisien model regresi memiliki nilai konstanta sebesar 14.87547 dengan nilai $t$-statistic sebesar I4.32466 dan nilai probabilitas sebesar 0.0000. Konstanta sebesar 14.87547 menandakan bahwa jika variabel independen konstan maka rata-rata Laba adalah sebesar |4.87547.

Hasil dari Tabel 3 menunjukkan bahwa NPF berpengaruh signifikan dan negatif terhadap Laba Bank Umum Syariah. Nilai probabilitas sebesar 0.0098, menunjukkan bahwa nilai probabilitas NPF < dari nilai $\alpha=5 \%$, maka $\mathrm{H}_{0}$ ditolak dan $\mathrm{H}_{\mathrm{a}}$ diterima. NPF memiliki nilai koefisien sebesar -0.270372. hal ini menunjukkan jika NPF 
mengalami kenaikan sebesar satu, maka akan mengurangi Laba sebesar 0.270372 .

Tabel 3. Hasil Estimasi Fixed Effect Model

\begin{tabular}{|c|c|c|c|c|c|}
\hline & Variable & Coefficient & Std. Error & t-Statistic & Prob. \\
\hline & C & 14.87547 & 1.038452 & 14.32466 & 0.0000 \\
\hline & NPF? & -0.270372 & 0.102433 & -2.639503 & 0.0098 \\
\hline & CAR? & -0.026179 & 0.020104 & -1.302173 & 0.1961 \\
\hline & BOPO? & -0.045325 & 0.012732 & -3.559797 & 0.0006 \\
\hline & PBGH? & 3.754416 & 1.111880 & 3.376637 & 0.0011 \\
\hline R-squared & & 0.614247 & & & \\
\hline Adjusted R-squa & & 0.580335 & & & \\
\hline F-statistic & & 18.11279 & & & \\
\hline $\operatorname{Prob}(F-$ statistic $)$ & & 0.000000 & & & \\
\hline
\end{tabular}

Sumber : Data Sekunder diolah

Hasil dari Tabel 3 menunjukkan bahwa CAR tidak berpengaruh signifikan terhadap Laba Bank Umum Syariah. Nilai probabilitas sebesar 0.196I, menunjukkan bahwa nilai probabilitas $C A R>$ dari nilai $\alpha=5 \%$, maka $\mathrm{H}_{0}$ diterima dan $\mathrm{H}_{\mathrm{a}}$ ditolak. CAR memiliki nilai koefisien sebesar -0.026179 . hal ini menunjukkan jika CAR mengalami kenaikan sebesar satu, maka akan mengurangi Laba sebesar -0.026179 .

Hasil dari Tabel 3 menunjukkan bahwa BOPO berpengaruh negatif dan signifikan terhadap Laba Bank Umum Syariah. Nilai probabilitas sebesar 0.0006, menunjukkan bahwa nilai probabilitas $\mathrm{BOPO}<$ dari nilai $\alpha=5 \%$, maka $\mathrm{H}_{0}$ ditolak dan $\mathrm{H}_{\mathrm{a}}$ diterima. BOPO memiliki nilai koefisien sebesar -0.045325 . hal ini menunjukkan jika BOPO mengalami kenaikan sebesar satu, maka akan mengurangi Laba sebesar 0.045325. Hasil dari Tabel 3 menunjukkan bahwa Komposisi dan Tingkat Konsentrasi Pembiayaan Bagi Hasil berpengaruh positif dan signifikan terhadap Laba Bank Umum Syariah. Nilai probabilitas sebesar $0.001 \mathrm{I}$, menunjukkan bahwa nilai probabilitas Komposisi dan Tingkat Konsentrasi Pembiayaan Bagi Hasil < dari nilai $\alpha=5 \%$, maka $\mathrm{H}_{0}$ 
ditolak dan $\mathrm{H}_{\mathrm{a}}$ diterima. Komposisi dan Tingkat Konsentrasi Pembiayaan Bagi Hasil memiliki nilai koefisien sebesar 3.7544I6. hal ini menunjukkan jika Komposisi dan Tingkat Konsentrasi Pembiayaan Bagi Hasil mengalami kenaikan sebesar satu, maka akan menaikkan Laba sebesar 3.7544I6.

Berdasarkan Tabel 3 didapatkan koefisien determinasi adjusted $R^{2}$ sebesar 0.580335 atau $58.03 \%$. Dapat disimpulkan bahwa pengaruh non performing financing (NPF), Capital Adequacy Ratio (CAR), Biaya Operasional Terhadap Pendapatan Operasional (BOPO) dan Komposisi dan Tingkat Konsentrasi Pembiayaan Bagi Hasil, terhadap laba Bank Umum Syariah adalah 58.03\%. Sedangkan sisanya sebesar $41.97 \%$ (100\% - 58.03\%) dipengaruhi oleh variabel-variabel lain yang tidak dimasukkan ke dalam penelitian ini misalnya seperti BI Rate, Giro Wajib Minimum (GWM), Financing to Deposit Ratio (FDR), Net Interest Margin (NIM), Dana Pihak Ketiga (DPK) dan lain-lain.

Variabel Non Performing Financing (NPF) berpengaruh signifikan dan negatif terhadap Laba Bank Umum Syariah. Hasil ini sesuai dengan penelitian Rahman (2009) yang menyatakan bahwa NPL berpengaruh signifikan dan negatif terhadap perubahan laba. Resiko pembiayaan merupakan resiko yang timbul akibat dari ketidakmampuan nasabah untuk mengembalikan sejumlah pinjaman yang diberikan oleh bank syariah beserta bagi hasilnya sesuai dengan jangka waktu yang telah ditentukan. Sehingga, dengan adanya keterlambatan pengembalian pinjaman dana akan berdampak pada keuntungan yang diperoleh bank syariah. Hasil analisis dalam penelitian ini sesuai dengan hipotesis yang menyatakan bahwa pembiayaan bermasalah atau Non Performing Financing (NPF) pada dasarnya berpengaruh terhadap Laba. Hal ini berarti bahwa, setiap kenaikan pembiayaan bermasalah sebesar satu persen maka akan menurunkan nilai laba. Terdapat faktor lain yang mempengaruhi Laba, seperti apa yang dijelaskan Pramuka dalam Afif dan Mawardi (2014) bahwa laba bersih suatu bank dipengaruhi dua faktor, yakni volume pembiayaan dan resiko pembiayaan.

Variabel Capital Adequacy Ratio (CAR) tidak berpengaruh terhadap Laba Bank Umum Syariah. Hasil penelitian ini sesuai dengan penelitian Nusantara (2009), yang menyatakan bahwa CAR tidak berpengaruh terhadap ROA pada bank non go publik. Dalam penelitian ini CAR tidak berpengaruh signifikan karena bank non go publik 
cenderung untuk menginvestasikan dananya dengan hati-hati dan lebih menekankan pada survival bank, sehingga CAR tidak berpengaruh banyak terhadap profitabilitas bank. Sedangkan, Widyaningrum dan Septiarini (2015) CAR tidak berpengaruh terhadap ROA disebabkan oleh sikap dari manajemen BPRS yang menjaga agar tingkat CAR pada BPRS tetap sesuai dengan ketetapan Bank Indonesia yaitu minimal $8 \%$ sehingga hal ini dapat menyebabkan BPRS tidak optimal dalam memanfaatkan modal yang dimiliki.

Variabel Biaya Operasional Terhadap Pendapatan Operasional (BOPO) berpengaruh negatif signifikan terhadap Laba Bank Umum Syariah. Pengaruh negatif dan signifikan BOPO terhadap Laba Bank Umum Syariah berarti bahwa setiap kenaikan BOPO sebesar satu menurunkan laba sebesar 0.045325 . Hasil penelitian ini sesuai dengan penelitian Anisah Lubis (2013) yang menyatakan bahwa rasio Biaya Operasional Terhadap Pendapatan Operasional (BOPO) berpengaruh negatif dan signifikan terhadap Pertumbuhan Laba pada BPR di Indonesia. Ubaidillah (2016) menyatakan bahwa ada pengaruh negatif dan signifikan antara rasio BOPO terhadap tingkat profitabilitas (ROA) pada bank syariah. Berbeda dengan penelitian Nuraini (2016) menyatakan bahwa BOPO tidak berpengaruh terhadap perubahan laba. BOPO merupakan rasio untuk menilai efisiensi suatu bank dengan cara mengendalikan biaya operasional nya terhadap pendapatan operasional yang dikeluarkan oleh bank. Hasil penelitian ini sesuai dengan teori bahwa semakin kecil rasio BOPO maka semakin efisien aktiva bank dalam menghasilkan laba. Ketetapan dari OJK untuk rasio BOPO adalah dibawah $90 \%$.

Variabel Komposisi dan Tingkat Konsentrasi Pembiayaan Bagi Hasil berpengaruh positif signifikan terhadap Laba Bank Umum Syariah.hasil penelitian ini sesuai dengan penelitian Amalia (2016) yang menyatakan bahwa pembiayaan mudharabah berpengaruh terhadap profitabilitas Bank Muamalat Indonesia dan Bank Syariah Mandiri. Hasil penelitian ini bertentangan dengan penelitian Haq (20I5) yang menyatakan bahwa pembiayaan bagi hasil tidak meningkatkan kemampuan bank syariah dalam meningkatkan labanya. Pembiayaan bagi hasil adalah suatu kegiatan operasional bank dalam bentuk penyaluran dana dengan sistem Profit and Loss Sharing yang tujuan utamanya adalah mencari keuntungan. Hasil penelitian ini sesuai dengan hipoteis 
bahwa pembiayaan bagi hasil mempunyai pengaruh terhadap Laba di Bank Syariah.

\section{SIMPULAN}

Dari hasil analisis data yang telah dilakukan dalam penelitian ini, dapat disimpulkan bahwa rasio keuangan penilaian tingkat kesehatan Risk Based Bank Rating yang mempengaruhi Laba pada Bank Umum Syariah adalah Non Performing Financing (NPF), biaya operasional terhadap pendapatan operasional (BOPO) serta Komposisi dan Tingkat Pembiayaan Berbasis Bagi Hasil. Sedangkan variabel Capital Adequacy Ratio (CAR) tidak berpengaruh terhadap Laba di Bank Umum Syariah. Pengujian Variabel Independen dilakukan dengan menggunakan data panel Fixed Effect Model (FEM) menunjukkan seluruh variabel secara bersama-sama memiliki pengaruh yang signifikan pada taraf nyata 5 persen terhadap Laba di Bank Umum Syariah. Secara parsial, variabel-variabel CAR tidak berpengaruh terhadap Laba di Bank Umum Syariah. Variabel NPF berpengaruh signifikan dan negatif terhadap Laba di Bank Umum Syariah. Variabel Komposisi dan Tingkat Pembiayaan Berbasis Bagi Hasil berpengaruh signifikan dan positif terhadap Laba di Bank Umum Syariah. Variabel BOPO berpengaruh signifikan dan negatif terhadap Laba di Bank Umum Syariah.

\section{PUSTAKA ACUAN}

Afif, Z. N. dan I. Mawardi. 20I4. Pengaruh Pembiayaan Murabahah terhadap Laba Melalui Variabel Intervening Pembiayaan Bermasalah Bank Umum Syariah di Indonesia Periode 2009-2013. Jurnal Ekonomi Syariah Toeri dan Terapan (JESTT) Volume I. No. 8..

Amalia, N. 2016. Struktur Pembiayaan dan Pengaruhnya terhadap Profitabilitas Bank Muamalat Indonesia dan Bank Syariah Mandiri. Jurnal IImu dan Riset Akuntansi, Vol. 5, No. 5..

Basuki, A.T. dan N. Prawoto. 2016. Analisis Regresi Dalam Penelitian Ekonomi dan Bisnis. Jakarta: Rajawali Pers. 
Ikatan Bankir Indonesia dan Bankir Association for Risk Management (BARa). 2016. Manajemen Kesehatan Bank Berbasis Resiko. Jakarta: PT Gramedia Pustaka Utama.

Lubis, A. 2013. Pengaruh Tingkat Kesehatan Bank terhadap Pertumbuhan Laba Pada BPR di Indonesia”, Jurnal Ekonomi dan Keuangan, Vol. I, No. 4: 2737.

Novitasari, D. R. 20I5. Pengaruh Tingkat Kesehatan Bank dengan Metode Camels terhadap Pertumbuhan Laba pada Bank Umum Syariah Periode 20II-20I4. Jurnal Universitas Negeri Surabaya, Vol. 3, No. 2 : I-20.

Nurdin, dkk. 2016. Pengaruh Rasio Risk Based Bank Rating terhadap Return on Equity Bank Mega Syariah, Jurnal Keuangan dan Perbankan Syariah. Vol. 2 (2): $662-666$

Nusantara, A.B. 2009. Analisis Pengaruh NPL, CAR, LDR, dan BOPO Terhadap Profitabilitas Bank (perbandingan bank umum Go publik dan Non Go Publik periode tahun 2005-2007). Tesis Tidak Dipublikasikan. Semarang: Universitas Diponogoro.

Rahman, T. 2009. Analisis Pengaruh Car, Nim, Bopo, Ldr, Npl terhadap Perubahan Laba (studi kasus pada bank non devisa di indonesia periode 2003-2007). Tesis Tidak Dipublikasikan. Semarang: Universitas Diponogoro.

Susilo, Y. Sri. dkk. 2000. Bank dan Lembaga Keuangan Lain. Jakarta: Salemba Empat.

Nuraini, N. 2016. Pengaruh Perubahan ROA, BOPO, NPM dan LDR terhadap Perubahan Laba. Jurnal Ilmu dan Riset Manajemen. Vol. 5 (7) : $1-17$.

Ubaidillah. 2016. Analisis Faktor-Faktor yang Mempengaruhi Profitabilitas Bank Syariah Di Indonesia. Jurnal Ekonomi Islam (Islamic Economics Journal), Vol. 4 (I): |5|-|88.

Usanti, T. P dan A. Shomad. 2013. Transaksi Bank Syariah Jakarta: PT. Bumi Aksara.

Widyaningrum, L. dan D. F. Septiarini. 2015. Pengaruh CAR, NPF, FDR, 
dan OER terhadap ROA Pada Bank Pembiayaan Rakyat Syariah di Indonesia Periode Januari 2009 Hingga Mei 20I4. Jurnal JESTT Vol. 2 (I2): 970-985. 